\title{
Effects of feeding naturally contaminated diet with zearalenone, fumonisin and deoxynivalenol with or without yeast cell wall adsorbent on growth, vulva size and organ weights of gilts
}

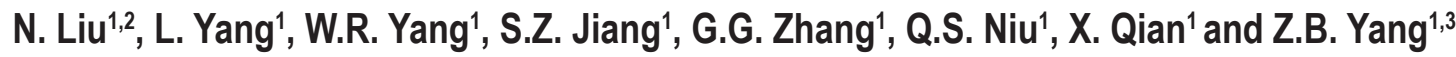 \\ ${ }^{1}$ Shandong Agricultural University, Department of Animal Sciences and Technology \\ Tai-an, Shandong, 271018, China \\ ${ }^{2}$ China Agricultural University, State Key Laboratory of Animal Nutrition \\ Beijing, 100083, China
}

KEY WORDS: gilts, growth, genital organs, vulva, Fusarium mycotoxins, yeast cell wall

Received: 30 November 2015

Revised: $\quad 16$ March 2016

Accepted: $\quad 23$ May 2016

${ }^{3}$ Corresponding author:

e-mail: zbyang204@163.com

\begin{abstract}
The aim of the study was to evaluate the effects of feeding naturally contaminated diet with Fusarium mycotoxins with or without yeast cell wall (YCW) on growth, vulva size, serum protein chemistry and organ weights of gilts. Forty gilts $(8.33 \pm 0.96 \mathrm{~kg})$ were fed for 30 days four different diets: 1. control, 2. naturally contaminated diet (NCD), 3. naturally contaminated diet $+0.10 \%$ YCW, 4. naturally contaminated diet $+0.25 \%$ YCW. After 30 days of feeding with NCD diet average daily gain (ADG), feed conversion ratio, final body weight, serum albumin concentration and relative weight of liver were reduced $(P<0.05)$ in comparison to control group. In contrast, vulva size and relative weight of genital organs were increased $(P<0.05)$ by mycotoxins. The $0.25 \%$ YCW addition diminished the NCD negative effect on ADG, albumin concentration, and liver and genital organs weights throughout 30 days $(P<0.05)$. The lower YCW addition reversed only the negative effect of mycotoxins on liver weight. The vulva length was decreased by higher YCW dose but only at day 12 . The addition of YCW could not ameliorate the enlarged vulva width and vulva area caused by mycotoxins. Based on the obtained results, it was showed that Fusarium mycotoxins lead to pernicious effects for gilts, but YCW addition to the diet can to some extent effectively ameliorate these detrimental mycotoxins effects.
\end{abstract}

\section{Introduction}

Some compounds, like mycotoxins, are toxic secondary metabolites produced by fungi or molds and are often found in grains or their derived products. As discussed in previous studies, it was revealed that feedstuffs used all over the world are seriously contaminated with zearalenone (ZEA), fumonisin (FUM), deoxynivalenol (DON) and other mycotoxins (Potkański et al., 2010). Additionally, the mycotoxin- induced toxic effects in humans and animals have earned extensive consideration (Kubizna et al., 2011). In subsequent studies, the obtained results showed that the toxic effect of mycotoxins was dependent on the source of mycotoxin (i.e. purified vs naturally contaminated) in the ingredient (Prelusky et al., 1994). However, individual mycotoxins are seldom present in feedstuffs alone. Moreover, toxicity and clinical signs are much more complex and diverse, especially, when at least one mycotoxin is present. 
To our knowledge, little data is available about the effects of low or medium doses of ZEA together with FUM and DON on gilt growth, vulva size, serum protein chemistry and organ weights.

To minimize the mycotoxin-caused losses in animal production and decrease mycotoxins concentration in the products of animal origin (like milk and meat), many physical, chemical, nutritional and biological approaches have been extensively investigated and evaluated (Jouany, 2007). Recently, yeast cell wall adsorbent (YCW) has been used as one of the approaches, as it has shown beneficial effects on preventing toxic effects in poultry and pigs; however, the conclusions are fragmentary and conflicting (Xiao et al., 2013; Kong et al., 2014). Hence, the current study was designed to evaluate the effects of feeding naturally contaminated diet with Fusarium mycotoxins on gilt performance, vulva size, serum protein chemistry and organ weights, and to test the efficacy of YCW in counteracting the adverse consequences of mycotoxins consumption.

\section{Material and methods}

This study was carried out in strict accordance with the recommendations in the Guide for the Care and Use of Laboratory Animals of Shandong Agricultural University Animal Nutrition Research Institute and the Ministry of Agriculture of China. The experimental protocol of this study was approved by the Committee on the Ethics of Shandong Agricultural University (Approval Number: S20130058).

\section{Adsorbents}

Detoxza $^{\circledR}$, a commercial yeast cell wall adsorbent (YCW), was obtained from $\mathrm{AB}$ Co Products Asia (Harbin, China). YCW was homogenously mixed into the diets.

\section{Experimental animals and diets}

Forty crossbred gilts (Duroc $\times$ Landrace $\times$ Large White) with an average initial body weight (BW) of $8.33 \pm 0.96 \mathrm{~kg}$ were individually maintained in metabolic cages $(0.6 \times 0.8 \mathrm{~m})$ in an environmentally controlled room (temperature $26-28{ }^{\circ} \mathrm{C}$, relative humidity $65 \%$ ). After 7 days of adaptation the animals were randomly allotted to 3 experimental groups and to a control group (10 animals in each, on the BW basis). Gilts had a free access to feed and water and were observed daily for any adverse clinical signs.

The control diet was formulated to meet or exceed the minimal requirements of NRC (1998). The naturally contaminated diet (NCD) was nutritionally similar, but $50 \%$ of control maize and $50 \%$ of con-
Table 1. Composition of control, naturally contaminated diet, and yeast cell wall adsorbent supplemented diets (as fed basis)

\begin{tabular}{|c|c|c|c|c|}
\hline \multirow{3}{*}{ Indices } & \multicolumn{4}{|c|}{ Diet } \\
\hline & \multirow{2}{*}{ control } & \multirow{2}{*}{$\mathrm{NCD}^{1}$} & \multicolumn{2}{|c|}{ YCW } \\
\hline & & & $0.10 \%^{2}$ & $0.25 \%^{2}$ \\
\hline \multicolumn{5}{|l|}{ Ingredient, \% } \\
\hline $\mathrm{YCW}^{2}$ & - & - & 0.1 & 0.25 \\
\hline maize & 61.7 & & 30.85 & \\
\hline contaminated maize & 0 & & 30.85 & \\
\hline maize gluten meal & 5 & & 2.50 & \\
\hline contaminated maize gluten meal & - & & 2.50 & \\
\hline soyabean meal $(46.0 \% \mathrm{CP})$ & & 24 & & \\
\hline whey powder & & 3 & 3 & \\
\hline soyabean oil & & & .5 & \\
\hline dicalcium-phosphate & & & .3 & \\
\hline limestone & & & .1 & \\
\hline sodium chloride & & & .4 & \\
\hline premix $^{3}$ & & & 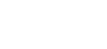 & \\
\hline \multicolumn{5}{|l|}{ Nutrient composition } \\
\hline digestible energy, $\mathrm{kcal} \cdot \mathrm{kg}^{-1}$ & & 340 & & \\
\hline crude protein ${ }^{4}, \%$ & & & 9.26 & \\
\hline $\mathrm{Ca}^{4}, \%$ & & & 0.82 & \\
\hline total $P^{4}, \%$ & & & 0.33 & \\
\hline sodium chloride ${ }^{4}, \%$ & & & 0.42 & \\
\hline lysine ${ }^{4}, \%$ & & & 1.11 & \\
\hline methionine ${ }^{4}, \%$ & & & 0.41 & \\
\hline cystine ${ }^{4}, \%$ & & & 0.78 & \\
\hline
\end{tabular}

${ }^{1} \mathrm{NCD}$ - naturally contaminated diet; ${ }^{2} \mathrm{YCW}$ - yeast cell wall adsorbent (AB Co Products, Harbin, China, Asia); $0.10 \%$ YCW or $0.25 \%$ YCW represents yeast cell wall adsorbent which was supplemented at the level of 1.0 or $2.5 \mathrm{~g} \cdot \mathrm{kg}^{-1}$, respectively; ${ }^{3}$ supplied per $\mathrm{kg}$ of diet: IU: vit. A 3.300, vit. $D_{3} 330$, vit. E 24 , mg: vit. $K_{3} 0.75$, vit. $B_{1} 1.50$, vit. $B_{2} 5.25$, vit. $B_{6} 2.25$, vit. $B_{12} 0.02625$, pantothenic 15.00 , niacin 22.5 , biotin 0.075 , folic acid 0.45, Mn 6.00, Fe 150, Zn 150, Cu 9.00, I 0.21, Se $0.45 ;{ }^{4}$ calculated

trol maize gluten meal was displaced with maize and maize gluten meal naturally contaminated with Fusarium mycotoxins (Table 1). To test the efficacy of YCW in preventing Fusarium mycotoxicoses, naturally contaminated diets were supplemented with 1.0 and $2.5 \mathrm{~g} \cdot \mathrm{kg}^{-1}$ of YCW. Representative feed samples were taken at the beginning of the experiment and were then analysed for Fusarium mycotoxins content.

\section{Analysis of mycotoxins}

The presence of zearalenone (ZEA) and fumonisin (FUM) was analysed by Animal Feeds and Veterinary Drugs Detection Station (Qingdao, China) as described by Gajęcka et al. (2013). Deoxynivalenol (DON) content was analysed using high performance liquid chromatography (HPLC) as presented by Swamy et al. (2003). The limits of detection were $0.10 \mathrm{ppm}$ for ZEA and DON and $0.25 \mathrm{ppm}$ for FUM. 


\section{Experimental parameters}

Body weight and feed consumption. The gilts were weighed individually, and feed intake for each block was determined at 10-day intervals. Feed conversion ratio $(\mathrm{FCR})$ was calculated as $\mathrm{g}$ gain $\cdot \mathrm{g}^{-1}$ feed.

Vulva size. Vulva length and width were measured at 6-day intervals, and vulva area was calculated approximately as a diamond shape ((vulva length $\times$ vulva width) $/ 2$ ).

Blood sample collection. On 15 and 30 day of the experiment, a jugular venous blood samples were obtained from each piglet. Blood was collected into a non-heparinized tubes, incubated at $37{ }^{\circ} \mathrm{C}$ for $2 \mathrm{~h}$, centrifuged at $1500 \mathrm{~g}$ for $10 \mathrm{~min}$, and the serum was separated and stored in tubes for serum protein chemistry analysis.

Serum protein concentration. Serum concentrations of total protein and albumin were determined by an automatic clinical chemistry analyzer (Hitachi 7600-020, Tokyo, Japan). Serum globulin content was calculated as the difference between total protein and albumin concentrations.

Organ weights. At the end of the experiment, gilts were weighed individually and euthanatized. Liver and genital organs, including ovary, cornu uteri and vaginal vestibule, were quickly isolated and weighed. Organ weights were expressed on a relative BW basis $\left(\mathrm{g} \cdot \mathrm{kg}^{-1}\right)$.

\section{Statistical analyses}

All data was statistically analysed using the GLM procedure of SAS (ver. 9.1, 2003; SAS Institute Inc., Cary, NC, USA). At first the data was analysed as a completely randomized design with individual gilt as random factor to examine the overall effect of treatments. The efficacy of supplemental YCW was determined by using a contrast between naturally contaminated diets and naturally contaminated diets with YCW. In all analyses, significant difference was declared at $P=0.05$. Probability of values between $0.05 \sim 0.10$ were considered as tendencies.

\section{Results}

\section{Mycotoxin analysis}

ZEA, FUM and DON presence was detected in all diets, however concentrations of ZEA, FUM and DON in control diet were lower than in NCD with or without YCW (Table 2). Aflatoxin, ochratoxins and T-2 toxin in diets were not detected or were below the detection limits.
Table 2. Mycotoxin content in experimental diets ${ }^{1}, \mu g \cdot \mathrm{kg}^{-1}$

\begin{tabular}{lrrrr}
\hline \multirow{2}{*}{ Mycotoxin } & \multicolumn{3}{c}{ Diet $^{2}$} \\
\cline { 2 - 5 } & control & NCD & $0.10 \%$ & $0.25 \%$ \\
\cline { 3 - 5 } Zearalenone & 47.5 & 849.4 & 823.0 & 884.2 \\
Fumonisin & 1364.2 & 5661.6 & 5604.7 & 5646.6 \\
Deoxynivalenol & 654.5 & 1576.8 & 1642.2 & 1643.4 \\
\hline
\end{tabular}

${ }^{1}$ aflatoxin, ochratoxins and T-2 toxin in any diet were not detected or were below the detection limit; ${ }^{2}$ see Table 1

\section{Growth performance}

Average daily gain (ADG), FCR and final BW (Table 3) were lower for gilts fed naturally contaminated diet than gilts fed the control diet during the overall period $(P<0.05)$. The addition of YCW at both doses $\left(1.0\right.$ or $\left.2.5 \mathrm{~g} \cdot \mathrm{kg}^{-1}\right)$ did not effectively ameliorate mycotoxins-stimulated reduction of the final BW and FCR during each period separately and in the whole experiment. The reduction of ADG was effectively prevented by the addition of a higher dose of YCW but only between 20 and 30 day $(P<0.05)$ and in the whole experimental period $(P<0.05)$.

Table 3. Effects of 30-day feeding naturally contaminated diets with or without yeast cell wall adsorbent on performance of piglets $(n=10)$

\begin{tabular}{|c|c|c|c|c|c|c|}
\hline \multirow{3}{*}{ Indices } & \multicolumn{4}{|c|}{$\operatorname{Diet}^{1}$} & \multirow{3}{*}{ SEM } & \multirow{3}{*}{$\begin{array}{l}P>F \\
N C D \text { vs } \\
Y C W^{2}\end{array}$} \\
\hline & \multirow{2}{*}{ control } & \multirow{2}{*}{ NCD } & \multicolumn{2}{|c|}{ YCW } & & \\
\hline & & & $10 \%$ & 0.25 & & \\
\hline \multicolumn{7}{|l|}{ Day 0 to 10} \\
\hline initial BW, kg & 8.34 & 8.32 & 8.32 & 8.33 & 0.315 & 0.988 \\
\hline$A D G, g \cdot d^{-1}$ & $500.3^{a}$ & $292.6^{b}$ & $346.5^{b}$ & $327.5^{b}$ & 35.067 & 0.264 \\
\hline ADFI, $g \cdot d^{-1}$ & 478.3 & 458.0 & 480.0 & 465.0 & 30.762 & 0.704 \\
\hline FCR & $1.04^{\mathrm{a}}$ & $0.65^{b}$ & $0.74^{b}$ & $0.71^{b}$ & 0.070 & 0.375 \\
\hline final & $4^{a}$ & $11.25^{b}$ & $11.79^{b}$ & $11.61^{b}$ & 0.508 & 0.424 \\
\hline \multicolumn{7}{|l|}{ ay 10 to 20} \\
\hline$A D G, g \cdot d^{-1}$ & $526.7^{\mathrm{a}}$ & $341.0^{b}$ & $370.7^{b}$ & $394.4^{b}$ & 23.096 & 0.038 \\
\hline ADFI, $g \cdot d^{-1}$ & 797.7 & 712.2 & 751.2 & 744.8 & 44.829 & 0.517 \\
\hline FCR & $0.67^{\mathrm{a}}$ & $0.48^{b}$ & $0.50^{\mathrm{b}}$ & $0.55^{b}$ & 0.037 & 0.274 \\
\hline final BW, kg & $3.61^{a}$ & $14.66^{b}$ & $15.50^{b}$ & $5^{b}$ & 0.656 & 0.184 \\
\hline \multicolumn{7}{|l|}{ Jay 20 to 30} \\
\hline$A D G, g \cdot d^{-1}$ & $567.4^{\mathrm{a}}$ & $348.6^{b}$ & $383.3^{b}$ & $480.4^{a}$ & 31.533 & 0.025 \\
\hline ADFI, $g \cdot d^{-1}$ & 1017.2 & 896.4 & 921.1 & 1017.5 & 56.345 & 0.295 \\
\hline FCR & $0.57^{a}$ & $0.39^{b}$ & $0.42^{b}$ & $0.49^{\mathrm{ab}}$ & 0.038 & 0.108 \\
\hline final BW, kg & $4.28^{a}$ & $18.14^{b}$ & $19.33^{b}$ & $20.35^{b}$ & 0.818 & 0.033 \\
\hline \multicolumn{7}{|l|}{ Jay 0 to 30} \\
\hline$A D G, g \cdot d^{-1}$ & $531.5^{\mathrm{a}}$ & $327.4^{c}$ & $366.8^{b c}$ & $400.8^{b}$ & 21.877 & 0.012 \\
\hline ADFI, $g \cdot d^{-1}$ & 764.4 & 688.9 & 717.4 & 742.4 & 39.799 & 0.405 \\
\hline FCR & $0.70^{\mathrm{a}}$ & $0.48^{\mathrm{b}}$ & $0.53^{b}$ & $0.55^{b}$ & 0.034 & 0.153 \\
\hline
\end{tabular}

${ }^{1}$ see Table $1 ;{ }^{2} \mathrm{NCD}$ vs YCW represents the contrast of the NCD treatment vs all YCW treatments; SEM - standard error of the mean; $B W$ - body weight; $A D G$ - average daily gain; ADFI - average daily feed intake; FCR - feed conversion ratio; abc - means with different superscripts within a column are significantly different $(P<0.05)$ 
Table 4. Effects of 30-day feeding naturally contaminated diets with or without yeast cell wall adsorbent on vulva size of piglets $(n=10)$

\begin{tabular}{|c|c|c|c|c|c|c|}
\hline \multirow{3}{*}{ Indices } & \multicolumn{4}{|c|}{ Diet $^{1}$} & \multirow{3}{*}{ SEM } & \multirow{3}{*}{$\begin{array}{l}P>F \\
N C D \text { vs } \\
Y C W^{2}\end{array}$} \\
\hline & \multirow{2}{*}{ control } & \multirow{2}{*}{ NCD } & \multicolumn{2}{|c|}{$\mathrm{YCW}^{2}$} & & \\
\hline & & & $0.10 \%$ & $0.25 \%$ & & \\
\hline \multicolumn{7}{|l|}{ Day 0} \\
\hline length, mm & 12.90 & 12.98 & 12.90 & 12.98 & 0.260 & 0.886 \\
\hline width, mm & 11.06 & 11.01 & 10.92 & 10.99 & 0.327 & 0.868 \\
\hline area $^{3}, \mathrm{~mm}^{2}$ & 71.03 & 71.42 & 70.62 & 71.45 & 2.472 & 0.889 \\
\hline \multicolumn{7}{|l|}{ Day 6} \\
\hline length, $\mathrm{mm}$ & $13.62^{b}$ & $18.32^{\mathrm{a}}$ & $16.64^{a}$ & $17.45^{\mathrm{a}}$ & 0.595 & 0.097 \\
\hline width, mm & $11.48^{b}$ & $13.89^{a}$ & $13.10^{a}$ & $13.87^{a}$ & 0.423 & 0.441 \\
\hline area, $\mathrm{mm}^{2}$ & $78.68^{b}$ & $128.40^{\mathrm{a}}$ & $109.15^{a}$ & $121.94^{\mathrm{a}}$ & 6.747 & 0.161 \\
\hline \multicolumn{7}{|l|}{ Day 12} \\
\hline length, mm & $14.55^{c}$ & $21.80^{a}$ & $20.36^{a b}$ & $20.08^{b}$ & 0.529 & 0.020 \\
\hline width, mm & $12.26^{b}$ & $16.12^{\mathrm{a}}$ & $16.18^{a}$ & $16.97^{a}$ & 0.463 & 0.446 \\
\hline area, $\mathrm{mm}^{2}$ & $89.57^{a}$ & $176.90^{\mathrm{a}}$ & $165.65^{a}$ & $170.81^{\mathrm{a}}$ & 7.997 & 0.419 \\
\hline \multicolumn{7}{|l|}{ Day 18} \\
\hline length, $\mathrm{mm}$ & $14.49^{b}$ & $24.05^{a}$ & $22.70^{a}$ & $22.59^{a}$ & 0.619 & 0.066 \\
\hline width, mm & $13.00^{b}$ & $18.52^{\mathrm{a}}$ & $18.23^{a}$ & $18.40^{a}$ & 0.605 & 0.788 \\
\hline area, $\mathrm{mm}^{2}$ & $94.43^{b}$ & $223.99^{a}$ & $208.01^{\mathrm{a}}$ & $209.35^{a}$ & 10.882 & 0.301 \\
\hline \multicolumn{7}{|l|}{ Day 24} \\
\hline length, mm & $15.29^{b}$ & $26.38^{a}$ & $25.11^{\mathrm{a}}$ & $24.58^{a}$ & 0.672 & 0.081 \\
\hline width, mm & $13.69^{b}$ & $19.98^{\mathrm{a}}$ & $20.74^{a}$ & $19.67^{\mathrm{a}}$ & 0.666 & 0.797 \\
\hline area, $\mathrm{mm}^{2}$ & $104.58^{b}$ & $264.20^{\mathrm{a}}$ & $263.01^{\mathrm{a}}$ & $243.55^{\mathrm{a}}$ & 13.215 & 0.554 \\
\hline \multicolumn{7}{|l|}{ Day 30} \\
\hline length, mm & $16.54^{b}$ & $28.74^{\mathrm{a}}$ & $28.26^{a}$ & $26.69^{a}$ & 0.899 & 0.285 \\
\hline width, $\mathrm{mm}$ & $14.34^{b}$ & $21.39^{a}$ & $22.04^{a}$ & $20.78^{a}$ & 0.591 & 0.980 \\
\hline area, $\mathrm{mm}^{2}$ & $118.80^{\mathrm{b}}$ & $308.71^{a}$ & $313.04^{a}$ & $279.68^{a}$ & 15.300 & 0.567 \\
\hline
\end{tabular}

${ }^{1}$ see Table 1, ${ }^{2}$ see Table 3; ${ }^{3}$ area $\left(\mathrm{mm}^{2}\right)=$ [width $(\mathrm{mm}) \times$ length $(\mathrm{mm})] / 2$; SEM - standard error of the mean; abc - means with different superscripts within a column are significantly different $(P<0.05)$

\section{Vulva size}

When gilts were exposed to naturally contaminated diets without $\mathrm{YCW}$, vulva was rapidly swelled as compared to control group starting from day 6 $(P<0.05$; Table 4$)$. The lower dose of YCW did not reverse the adverse effect of NCD on vulva size. The supplementation of a higher dose of YCW reduced the vulva length caused by NCD but only on day $12(P=0.02)$. The YCW addition also tended to decrease the vulva length increased by NCD on day $18(P=0.066)$ and $24(P=0.081)$.

\section{Serum protein chemistry}

In comparison to the control group the naturally contaminated diet without YCW reduced only serum albumin concentration on day $30(P<0.05$; Table 5), whereas albumin concentration on day 15 , total protein and globulin concentrations on day 15 and 30 were not significantly affected by mycotoxins presence in the diet $(P>0.05)$. The YCW addition (both doses) decreased total protein, albumin and globulin serum concentrations on day $15(P<0.05)$
Table 5. Effects of 30-day feeding naturally contaminated diets with or without yeast cell wall adsorbent on serum protein concentrations of piglets $(n=10)$

\begin{tabular}{|c|c|c|c|c|c|c|}
\hline \multirow{3}{*}{ Indices } & \multicolumn{4}{|c|}{ Diet $^{1}$} & \multirow{3}{*}{ SEM } & \multirow{3}{*}{$\begin{array}{l}P>F \\
N C D \text { vs } \\
Y C W^{2}\end{array}$} \\
\hline & \multirow{2}{*}{ control } & \multirow{2}{*}{ NCD } & \multicolumn{2}{|c|}{ YCW } & & \\
\hline & & & $0.10 \%$ & $0.25 \%$ & & \\
\hline \multicolumn{7}{|l|}{ Day 15} \\
\hline total protein, $\mathrm{g} \cdot \mathrm{l}^{-1}$ & $47.89^{a}$ & $43.02^{\mathrm{ab}}$ & $35.89^{c}$ & $39.33^{b c}$ & 2.105 & 0.044 \\
\hline albumin, $\left.g \cdot\right|^{-1}$ & $24.83^{a}$ & $22.07^{\mathrm{ab}}$ & $19.07^{b}$ & $20.56^{b}$ & 1.082 & 0.109 \\
\hline globulin, $\left.g \cdot\right|^{-1}$ & $23.06^{a}$ & $20.96^{\mathrm{ab}}$ & $16.82^{b}$ & $18.77^{\mathrm{ab}}$ & 1.581 & 0.081 \\
\hline \multicolumn{7}{|l|}{ Day 30} \\
\hline total protein, $\mathrm{g} \cdot \mathrm{l}^{-1}$ & $50.72^{b}$ & $46.89^{b}$ & $49.99^{b}$ & $56.86^{a}$ & 2.126 & 0.019 \\
\hline albumin, $g \cdot l^{-1}$ & $26.07^{a}$ & $22.43^{b}$ & $23.61^{a b}$ & $26.28^{a}$ & 1.063 & 0.080 \\
\hline globulin, $\mathrm{g} \cdot \mathrm{I}^{-1}$ & $24.66^{b}$ & $24.46^{b}$ & $26.38^{\mathrm{ab}}$ & $30.59^{a}$ & 1.867 & 0.070 \\
\hline
\end{tabular}

${ }^{1}$ see Table 1, ${ }^{2}$ see Table 3; SEM - standard error of the mean; abc - means with different superscripts within a column are significantly different $(P<0.05)$

in comparison to control and NCD group. On day 30 the presence of the higher dose of YCW in the diet increased total protein and globulin concentrations $(P<0.05)$ in comparison to control and NCD group. The $0.25 \%$ addition of YCW also prevented from the negative influence of NCD on albumin concentration on day $30(P<0.05)$.

\section{Organ weights}

The presence of mycotoxins in the diet increased the relative weight of genital organs $(P<0.05$; Figure 1), and reduced the relative weight of liver $(P<0.05$; Figure 2$)$ as compared to the control group. The presence of YCW at a dose of $1.0 \mathrm{~g} \cdot \mathrm{kg}^{-1}$ in the diet did not effectively reverse mycotoxins-stimulated relative weight changes of genital organs, but

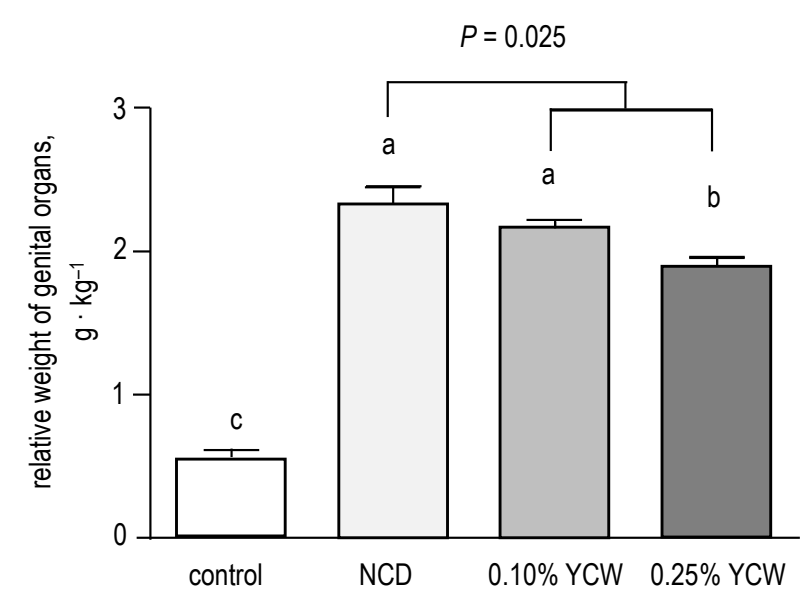

Figure 1. Effects of 30-day feeding naturally contaminated diets with or without yeast cell wall adsorbent on relative weight of genital organs of gilts. NCD - naturally contaminated diet with zearalenone, fumonisin and deoxynivalenol; YCW - yeast cell wall adsorbent; 0.10\% YCW or $0.25 \%$ YCW represents yeast cell wall adsorbent which was supplemented at the level of 1.0 or $2.5 \mathrm{~g} \cdot \mathrm{kg}^{-1}$, respectively; bars with different letters are significantly different at $P<0.05(n=10)$ 


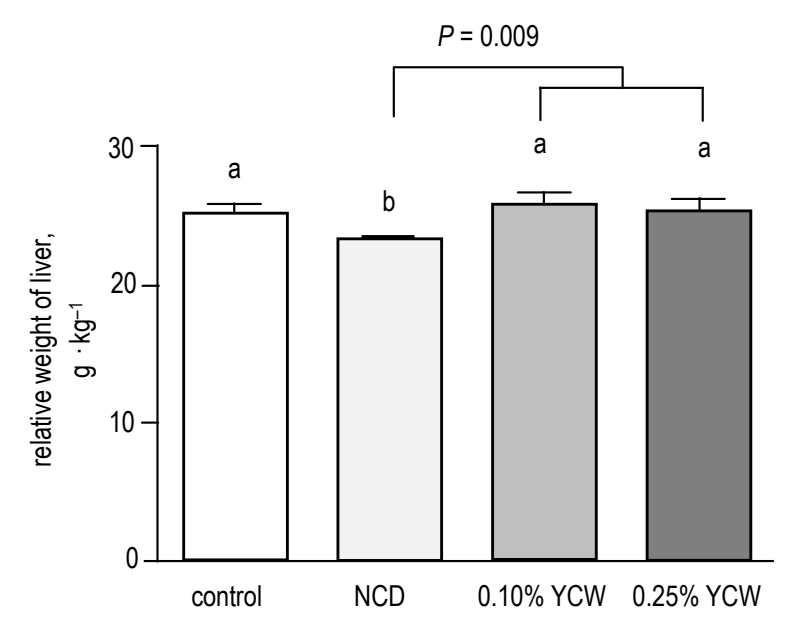

Figure 2. Effects of the 30-day feeding naturally contaminated diets with or without yeast cell wall adsorbent on relative weight of liver of gilts. NCD - naturally contaminated diet with zearalenone, fumonisin and deoxynivalenol; YCW - yeast cell wall adsorbent; $0.10 \%$ YCW or $0.25 \%$ YCW represents yeast cell wall adsorbent which was supplemented at the level of 1.0 or $2.5 \mathrm{~g} \cdot \mathrm{kg}^{-1}$, respectively; bars with different letters are significantly different at $P<0.05(n=10)$

prevented from the negative liver relative weight decrease $(P<0.05)$. The higher YCW dose also increased relative weight of liver in comparison to NCD group but it also diminished the adverse impact of mycotoxins on genital organs weight $(P<0.05)$.

\section{Discussion}

Dietary mycotoxins concentrations. In the present study, it was demonstrated that ZEA, FUM and DON were the main mycotoxin contaminants in the diet naturally contaminated diet with Fusarium mycotoxins. The effects of mycotoxins and their metabolites could lead to additive and synergistic mycotoxicoses, even if the combined toxins contents were not as high as in purified ones (Prelusky et al., 1994). Likewise, conjugated mycotoxins, which usually bind to a more polar substance, such as glucose, are referred to as 'masked' mycotoxins (Berthiller et al., 2009). These mycotoxins could be not detected by a routine detection method but can be released after hydrolysis in vivo (Dall'Asta et al., 2009). In the control diet ZEA, FUM and DON were unexpectedly detected, although each ingredient was selected very carefully, which shows that feedstuffs are extensively contaminated with mycotoxins in China. However, the contents of ZEA, FUM and DON in the control diet were within the requirements for animal feeds of the State Standard of China (GB, 2001, 2006).

Growth performance. The current study demonstrated that feeding naturally contaminated diet with Fusarium mycotoxins negatively affected gilt performance. Feed intake reduction and consequently decreased BW gain were commonly obtained and are considered as the main detrimental effects of Fusarium mycotoxins on pigs (Goyarts et al., 2005; Mok et al., 2013) so as in the present study. Additionally, FCR reduction observed in gilts fed naturally contaminated diets is in line with the previous reports (Smith et al., 1997), and may be caused by the synergistic effect of ZEA, FUM and DON. In contrast, other previous studies demonstrated a dramatic reduction of feed intake but no effect (Swamy et al., 2002) or an increase (Rotter et al., 1994) in FCR. The differences among studies on pigs may be possibly species- (different sex, age, BW or physiology of pigs), toxin- (mycotoxin type) and dosage-dependent (Goyarts et al., 2005).

Vulva size and genital organs weights. It is known that zearalenone leads to hyperoestrogenosis in pigs. Swelling vulva, prolapse of vagina and rectum, and enlargement of the mammary glands are the typical clinical symptoms caused by ZEA (Gajęcki et al., 2009). Also, in the present study after 6 days of feeding diet contaminated with ZEA and other mycotoxins a swollen vulva was observed and after 30 day the gilts showed a $73.7 \%, 49.2 \%$ and $159.9 \%$ increase in vulva length, width and area, respectively. This is in agreement with Jiang et al. (2010) who reported a rise of genital organ weights in animals fed diets containing $1,050 \mu \mathrm{g} \cdot \mathrm{kg}^{-1}$ purified ZEA. In the present study the swelled vulva was not ameliorated by the addition of YCW. Additionally, vulva vaginitis and enlarged reproductive tracts were also observed after feeding naturally ZEA contaminated diets with or without YCW (ZEA $\mu \mathrm{g} \cdot \mathrm{kg}^{-1}: 849.40$; $823.00 ; 884.20)$ which is consistent with the findings of Etienne and Jemmali (1982) who observed that uterus weight was nearly doubled in gilts ingested 3.61 and $4.33 \mathrm{mg} \cdot \mathrm{kg}^{-1}$ ZEA. Likewise, vulva vaginitis and enlarged reproductive tracts were also observed in gilts after feeding ZEA orally in gelatine capsules at doses $3.5,7.5$ or $11.5 \mathrm{mg} \cdot \mathrm{kg}^{-1} \mathrm{BW}$ (Farnworth and Trenholm, 1981). In this study, gilts exposed to naturally contaminated diets had increased vulva size and ovary-uterus weights. However, supplementation with YCW showed positive effect only on the reduction of the relative weight of genital organs.

Serum protein chemistry and liver weight. It is generally known that serum total protein, albumin, globulin and their alterations are index of liver damage and altered immune functions (Busher, 1990). Swamy et al. (2003) showed that serum total protein and globulin concentrations were decreased when piglets were fed grains naturally contaminated with 
Fusarium mycotoxins when compared to the controls. Likewise, the reduction of serum total protein concentrations was observed on day 30 . In addition, the reduction of serum albumin concentrations was also found. However, globulin concentrations were not affected by the naturally contaminated diet. So, the reduction of serum protein concentrations may be due to the metabolic effect of ZEA, FUM and DON or its synergetic effect in the liver, which affects DNA and protein syntheses (Abid-Essefi et al., 2004; Speijers and Speijers, 2004). This variation in results of piglets fed naturally contaminated diet might be the result of differences in age of pigs, types of grain as mycotoxin sources, different doses of Fusarium mycotoxins, and the presence of other Fusarium mycotoxins as well as volume of blood sample collected (Dänicke et al., 2004).

The present study showed that continuous feeding of naturally contaminated diets for 30 days, greatly decreased the relative liver weight of gilts, which is in line with findings of Swamy et al. (2002), but contradictory to Trenholm et al. (1994) who found a significant increase in liver weight of pigs fed 3.9, 5.0 and $8.7 \mathrm{mg} \cdot \mathrm{kg}^{-1}$ DON from contaminated wheat for 42 days. Also, the organ weights of mice fed mycotoxins were directly related to the animal nutritional status and organ mass changes in proportion to changes in body weight (Sun et al., 2014).

Effect of yeast cell wall adsorbent. One of the approaches for preventing mycotoxicosis in animals and minimizing absorption of mycotoxins from naturally contaminated feeds is to use YCW (Yiannikouris et al., 2004). Although the acute mode of action of YCW is not clear, Raju and Devegowda (2000) hypothesized that mycotoxin molecule might be attached to glucomannan matrix from YCW which prevents toxin absorption from intestinal tract and the subsequent toxin-induced tissue damages. Previous studies in our laboratory indicated that dietary addition of YCW at the level of $0.20 \%$ to naturally contaminated diets caused a protective effect on liver and spleen at 21 day of age, relative weight of bursa of fabricius and thymus at 42 day of age, antibody titers of Newcastle disease at both 28 and 42 day of age of broilers ( $\mathrm{Li}$ et al., 2012; Jiang et al., 2014).

Moreover, the results obtained in the current study showed that YCW added at up to $0.10 \%$ to the diet containing ZEA $\left(823.00 \mu \mathrm{g} \cdot \mathrm{kg}^{-1}\right)$, FUM (5 $604.70 \mu \mathrm{g} \cdot \mathrm{kg}^{-1}$ ) and DON (1 $642.15 \mu \mathrm{g} \cdot \mathrm{kg}^{-1}$ ) was less effective in protecting gilts from negative effects of naturally contaminated diets except the relative weight of the liver on day 30 . The improved results of weight gain, relative weight of liver and genital organs, and albumin concentration on day 30 in this study demonstrated that the $0.25 \% \mathrm{YCW}$ reduced the toxicity of Fusarium mycotoxins better than lower dose. It may suggest that YCW effectively adsorbed and sequestered mycotoxins, resulting in the reduction of toxin bioavailability. Further examinations are needed to evaluate the effect of YCW addition to different diets and to define the optimum YCW to mycotoxins ratio for the reduction of mycotoxins toxicity in gilts.

\section{Conclusions}

This is the first study which has indicated that zearalenone toxicity to genital organs could occur at concentrations as low as $849.4 \mu \mathrm{g} \cdot \mathrm{kg}^{-1}$ combined with fumonisin and deoxynivalenol presence. The current study suggests that mycotoxins induce deleterious effects on growth performance, serum protein chemistry and organ weights, however these effects could be partly prevented by the addition of the yeast cell wall adsorbent into the gilt diets.

\section{References}

Abid-Essefi S., Ouanes Z., Hassen W., Baudrimont I., Creppy E., Bacha H., 2004. Cytotoxicity, inhibition of DNA and protein syntheses and oxidative damage in cultured cells exposed to zearalenone. Toxicol. Vitro 18, 467-474

Berthiller F., Schuhmacher R., Adam G., Krska R., 2009. Formation, determination and significance of masked and other conjugated mycotoxins. Anal. Bioanal. Chem. 395, 1243-1252

Busher J.T., 1990. Serum albumin and globulin. In: H. Walker, W. Hall, J. Hurst (Editors). Clinical Methods: The History, Physical, and Laboratory Examinations. Butterworths, Boston, MA (USA)

Dall'Asta C., Mangia M., Berthiller F., Molinelli A., Sulyok M., Schuhmacher R., Krska R., Galaverna G., Dossena A., Marchelli R., 2009. Difficulties in fumonisin determination: the issue of hidden fumonisins. Anal. Bioanal. Chem. 395, 1335-1345

Dänicke S., Valenta H., Klobasa F., Döll S., Ganter M., Flachowsky G., 2004. Effects of graded levels of Fusarium toxin contaminated wheat in diets for fattening pigs on growth performance, nutrient digestibility, deoxynivalenol balance and clinical serum characteristics. Arch. Anim. Nutr. 58, 1-17

Etienne M., Jemmali M., 1982. Effects of zearalenone (F2) on estrous activity and reproduction in gilts. J. Anim. Sci. 55, 1-10

Farnworth E.R., Trenholm H.L., 1981. The effect of acute administration of the mycotoxin zearalenone to female pigs. J. Environ. Sci. Health B. 16, 239-252

Gajęcka M., Stopa E., Tarasiuk M., Zielonka Ł., Gajęcki M., 2013. The expression of type-1 and type-2 nitric oxide synthase in selected tissues of the gastrointestinal tract during mixed mycotoxicosis. Toxins 5, 2281-2292

Gajęcki M., Gajęcka M., Jakimiuk E., Zielonka Ł., Obremski K., 2010. Zearalenone - undesirable substance. In: R. Mahendra, V. Ajit (Editors). Mycotoxins in Food, Feed and Bioweapons. Springer-Verlag, Berlin Heidelberg (Germany), pp. 131-144 
GB, 2001. 13078 Hygienical Standard for Feeds. People's Republic of China

GB, 2006. 13078.2 Hygienical Standard for Feeds - Toleration of Ochratoxin $A$ and Zearalenone in Feeds. People's Republic of China

Goyarts T., Dänicke S., Rothkötter H.-J., Spilke J., Tiemann U., Schollenberger M., 2005. On the effects of a chronic deoxynivalenol intoxication on performance, haematological and serum parameters of pigs when diets are offered either for ad libitum consumption or fed restrictively. J. Vet. Med. A Physiol. Pathol. Clin. Med. 52, 305-314

Jiang S.Z., Li Z., Wang G.Y., Yang Z.B., Yang W.R., Zhang G.G., Wu Y.B., 2014. Effects of Fusarium mycotoxins with yeast cell wall adsorbent on hematology, serum biochemistry, and oxidative stress in broiler chickens. J. Appl. Poultry Res. 23, 165-173

Jiang S.Z., Yang Z.B., Yang W.R., Yao B.Q., Zhao H., Liu F.X., Chen C.C., Chi F., 2010. Effects of feeding purified zearalenone contaminated diets with or without clay enterosorbent on growth, nutrient availability, and genital organs in postweaning female pigs. Asian-Australas. J. Anim. Sci. 23, 74-81

Jouany J.P., 2007. Methods for preventing, decontaminating and minimizing the toxicity of mycotoxins in feeds. Anim. Feed Sci. Tech. 137, 342-362

Kong C., Shin S.Y., Kim B.G., 2014. Evaluation of mycotoxin sequestering agents for aflatoxin and deoxynivalenol: an in vitro approach. SpringerPlus 3, 346, doi: 10.1186/2193-1801-3-346

Kubizna J., Jamroz D., Kubizna J.K., 2011 Contamination of feed mixtures with mycoflora in South-Western Poland. Electron. J. Polish Agric. Univ., Ser. Vet. Med. 14, \#08

Li Z., Yang Z.B., Yang W.R., Wang S.J., Jiang S.Z., Wu Y.B., 2012. Effects of feed-borne Fusarium mycotoxins with or without yeast cell wall adsorbent on organ weight, serum biochemistry, and immunological parameters of broiler chickens. Poultry Sci, 91, 2487-2495

Mok C.H., Shin S.Y., Kim B.G., 2013. Aflatoxin, deoxynivalenol, and zearalenone in swine diets: Predictions on growth performance. Rev. Colomb. Cienc. Pecu. 26, 243-254

NRC, 1998. Nutrient Requirements of Swine. $10^{\text {th }}$ Edition. National Academy Press. Washington, DC

Potkański A., Grajewski J., Twarużek M., Selwet M., Miklaszewska B., Błatej-Kosicka A., Szumacher-Strabel M., Cieślak A., Raczkowska-Werwińska K., 2010. Chemical composition, fungal microflora and mycotoxin content in maize silages infected by smut (Ustilago maydis) and the effect of biological and chemical additives on silage aerobic stability. J. Anim. Feed Sci. 19, 130-142
Prelusky D.B., Gerdes R.G., Underhill K.L., Rotter B.A., Jui P.Y., Trenholm H.L., 1994. Effects of low-level dietary deoxynivalenol on haematological and clinical parameters of the pig. Nat. Toxins 2, 97-104

Raju M.V.L.N., Devegowda G., 2000. Influence of esterified-glucomannan on performance and organ morphology, serum biochemistry and haematology in broilers exposed to individual and combined mycotoxicosis (aflatoxin, ochratoxin and T-2 toxin). Brit. Poultry Sci. 41, 640-650

Rotter B.A., Thompson B.K., Lessard M., Trenholm H.L., Tryphonas H., 1994. Influence of low-level exposure to Fusarium mycotoxins on selected immunological and hematological parameters in young swine. Toxicol. Sci. 23, 117-124

Smith T.K., McMillan E.G., Castillo J.B., 1997. Effect of feeding blends of Fusarium mycotoxin-contaminated grains containing deoxynivalenol and fusaric acid on growth and feed consumption of immature swine. J. Anim. Sci. 75, 2184-2191

Speijers G.J.A., Speijers M.H.M., 2004. Combined toxic effects of mycotoxins. Toxicol. Lett. 153, 91-98

Sun L.-H., Lei M.-Y., Zhang N.-Y., Zhao L., Krumm C.S., Qi D.-S., 2014. Hepatotoxic effects of mycotoxin combinations in mice. Food Chem. Toxicol. 74, 289-293

Swamy H.V.L.N., Smith T.K., MacDonald E.J., Boermans H.J., Squires E.J., 2002. Effects of feeding a blend of grains naturally contaminated with Fusarium mycotoxins on swine performance, brain regional neurochemistry, and serum chemistry and the efficacy of a polymeric glucomannan mycotoxin adsorbent. J. Anim. Sci. 80, 3257-3267

Swamy H.V.L.N., Smith T.K., MacDonald E.J., Karrow N.A., Woodward B., Boermans H.J., 2003. Effects of feeding a blend of grains naturally contaminated with Fusarium mycotoxins on growth and immunological measurements of starter pigs, and the efficacy of a polymeric glucomannan mycotoxin adsorbent. J. Anim. Sci. 81, 2792-2803

Trenholm H.L., Foster B.C., Charmley L.L., Thompson B.K., Hartin K.E., Coppock R.W., Albassam M.A., 1994. Effects of feeding diets containing Fusarium (naturally) contaminated wheat or pure deoxynivalenol (DON) in growing pigs. Can. J. Anim. Sci. $74,361-369$

Xiao H., Wu M.M., Tan B.E., Yin Y.L., Li T.J., Xiao D.F., Li L., 2013. Effects of composite antimicrobial peptides in weanling piglets challenged with deoxynivalenol: I. Growth performance, immune function, and antioxidation capacity. J. Anim. Sci. 91, 4772-4780

Yiannikouris A., François J., Poughon L., Dussap C.-G., Bertin G., Jeminet G., Jouany J.-P., 2004. Alkali extraction of $\beta$-Dglucans from Saccharomyces cerevisiae cell wall and study of their adsorptive properties towards zearalenone. J. Agr. Food Chem. 53, 3666-3673 